\title{
RECOGNITION AND ENFORCEMENT OF JUDGMENTS IN COMMERCIAL MATTERS RENDERED BY COURTS OF NON-EU COUNTRIES IN THE CZECH REPUBLIC
}

\author{
MAGDALENA PFEIFFER, MARTA ZAVADILOVÁ
}

\begin{abstract}
The article deals with the conditions under which Czech courts recognise and enforce judgments rendered in commercial matters by courts outside of the EU. The relevant rules on recognition and enforcement are contained in both the Czech Act on Private International Law and in a number of international treaties binding for the Czech Republic. The authors analyse in detail the Czech national rules with particular emphasis on grounds for non-recognition and on the enforcement procedure, including relevant national case-law. As the Czech Republic is bound by a significant number of bilateral treaties on legal assistance that contain relevant provisions, the authors also bring a brief overview of the rules therein.
\end{abstract}

Keywords: international civil procedural law; recognition; enforcement; foreign judgments; commercial matters

DOI: $10.14712 / 23366478.2020 .39$

\section{INTRODUCTION}

The enforcement of judgments rendered by foreign courts is far from automatic. Following the principle of territoriality, judgments have authority and effects limited only to the territory of the state whose courts rendered them. ${ }^{1}$ It is up to every sovereign state if and under which conditions it will recognise judgments given by courts in another jurisdiction on its own territory. The aim of this paper is to present an overall analysis of the conditions for enforcement ${ }^{2}$ of judgments rendered in commercial matters by courts outside of the European Union in the territory of the Czech Republic. The conditions under which the Czech Republic recognises the authority and attaches effects to foreign judgments in commercial matters vary according to the judgment's country of origin. As set out in more detail below, they vary depending on whether the foreign judgment in commercial matters is enforced based on EU law, international treaty or Czech national rules. But in every case only those foreign judgments that are recognised, can be enforced. Recognition is a conditio sine qua non of enforcement.

1 VAŠKE, V. Uznáni a výkon cizich rozhodnutí v České republice. Praha: C. H. Beck, 2007, p. 35.

2 For purposes of this paper "enforcement" includes both the conditions and the procedure for enforcement of foreign judgments. 
In cross-border commercial litigation the issue of enforcement plays a vital role. ${ }^{3}$ If forum shopping is available, the plaintiff should consider enforcement chances already when looking for the most appropriate forum to file the suit. It is advisable to assess in advance whether, if litigating successfully in country A, the judgment given in country A can be enforced in country B, where the defendant has assets. If not, the plaintiff should consider instituting proceedings either in country B that will then enforce it as a national judgment rendered by its own courts, or in country $\mathrm{C}$ provided enforcement of judgments rendered by courts in country $\mathrm{C}$ is ensured in country $\mathrm{B}$.

In international trade, we often hear about trade barriers, meaning restrictions of an economic nature imposed by governments to restrain the free flow of goods and services. But it is important to bear in mind that besides the economic barriers like tariffs, subsidies, licences or quotas, there are also significant legal barriers that may deter businesses from trading cross-border. In the field of private international law, the uncertainty with respect to enforcement of judgments in foreign jurisdictions may represent one of the indirect hurdles to international trade. ${ }^{4}$ To overcome this uncertainty, business partners from different countries often opt for commercial arbitration to resolve their disputes because there is a unified global enforcement regime for arbitral awards in place that ensures a straightforward and simple enforcement procedure. The $1958 \mathrm{New}$ York Convention on Recognition and Enforcement of Foreign Arbitral Awards (hereinafter "New York Convention") 5 with its more than 160 contracting parties is the most successful multilateral treaty in the field of private international law and in large part responsible for the success of commercial arbitration. For the enforcement of judgments given in commercial matters, there had not been a comparable multilateral convention until 2019, when the Convention on the Recognition and Enforcement of Foreign Judgments in Civil or Commercial Matters (hereinafter "Hague Judgments Convention") ${ }^{6}$ was adopted under the auspices of the Hague Conference of Private International Law (hereinafter "Hague Conference"). Undoubtedly, it is a huge step forward, but there is still a long way to a unified global enforcement regime for judgments in commercial matters. The success of the Hague Judgments Convention will depend on the number of future contracting states.

Within the EU there is a well-functioning unified regime for the recognition and enforcement of judgments in commercial matters rendered by courts of the EU countries in the Brussels Ibis Regulation ${ }^{7}$ that ensures their free circulation in all, now $27,{ }^{8} \mathrm{EU}$

3 FENTIMAN, R. International Commercial Litigation. Second Edition. Oxford: Oxford University Press, 2015.

4 Report on the Convention on Jurisdiction and the Enforcement of Judgments in Civil and Commercial Matters (signed at Brussels, 27 September 1968) by Mr. P. Jenard. OJ C 59/1, 5. 3. 1979, p. 3.

5 UNTC. United Nations Treaty Collection. [online]. Accessed [August 30, 2019] at: https://treaties.un.org $/$ Pages/ViewDetails.aspx?src=TREATY\&mtdsg no=XXII-1\&chapter $=22 \&$ clang $=$ en.

6 HCCH $\mid \# 41-$ Full text. HCCH $\mid$ Splash. [online]. Copyright ${ }^{\circ}$ HCCH 1951. Accessed [August 30, 2019] at: https://www.hcch.net/en/instruments/conventions/full-text/?cid=137.

7 Regulation (EU) No 1215/2012 of the European Parliament and of the Council of 12 December 2012 on jurisdiction and the recognition and enforcement of judgments in civil and commercial matters (recast).

8 Great Britain formally left the EU on January 31, 2020 and under the terms of the Withdrawal Agreement will cease to apply the Brussels Ibis Regulation from 1 January 2021. 
Member States. ${ }^{9}$ The rules that were originally adopted in the Brussels Convention and Brussels I Regulation to enhance proper functioning of the internal market ensure that judgments given by the courts of one EU Member State in commercial matters are treated as if they had been given in the Member State where enforcement is sought. ${ }^{10}$ This unified regime is limited only to judgments rendered by courts in the EU; the treatment of judgments rendered by courts outside of the EU is left to national law subject to international treaties. There has been some, though limited, discussion in the EU on whether to unify the rules on the recognition and enforcement of judgments of courts given in non-EU countries and how to conceive such rules. ${ }^{11}$ In 2008 the GEDIP ${ }^{12}$ prepared a Proposal for Amendment of the Brussels I Regulation ${ }^{13}$ that included also provisions on the recognition and enforcement of judgments given in a state which is not a member of the EU, but avoided any analysis of the political desirability of such unification. ${ }^{14}$ The majority of the proposed amendments were not reflected in the recast, the EU regulation on the relationship to non-EU countries thus remains one of the private international law issues calling for a more consistent approach. ${ }^{15}$ Provided the EU joins the Hague Judgments Convention, it is to be expected that it will seek to promote the convention with third states to attract as many of them as possible for the convention to become a future dignified counterpart to the New York Convention.

\section{LEGAL FRAMEWORK}

\subsection{CZECH NATIONAL RULES}

Rules on the recognition and enforcement of foreign judgments that are rules of international civil procedural law and under the Czech doctrine part of private international law are contained in the Czech Act on Private International Law (hereinafter "Czech PILA"). ${ }^{16}$ General provisions in Sections 14-16 of the Czech PILA apply to judgments in commercial matters, provided the judgment was given by court of a country that is not an EU Member State and provided the Czech Republic and the country whose courts rendered the judgment are not parties to an international treaty laying down special rules for recognition and enforcement. Sections 17-19 of the Czech PILA contain special procedural rules that apply when the enforcement of a foreign judgment is subject to a declaration of enforceability (exequatur) required prior to the enforcement

\footnotetext{
9 In Denmark based on the Agreement between the European Community and the Kingdom of Denmark on jurisdiction and the recognition and enforcement of judgments in civil and commercial matters, signed at Brussels on 19 October 2005.

10 Recital (26) Brussels Ibis Regulation.

11 In detail see: BONOMI, A. European Private International Law and Third States. IPRax, 2017, No. 2, pp. 190-193.

12 European Group for Private International Law.

13 Council Regulation (EC) No 44/2001 of 22 December 2000 on jurisdiction and the recognition and enforcement of judgments in civil and commercial matters.

14 Consolidated version of a proposal to amend Regulation 44/2001 in order to apply it to external situations (Bergen 2008, Padua 2009, Copenhagen 2010).

15 BONOMI, op. cit., p. 193.

16 Act No. 91/2019 Coll., on Private International Law.
} 
of foreign judgments in other than commercial matters by certain EU Regulations and international treaties. ${ }^{17}$

\subsection{RELEVANT BILATERAL TREATIES ON LEGAL ASSISTANCE IN CIVIL MATTERS}

The Czech Republic is bound by a number of bilateral treaties on legal assistance in civil matters concluded with countries outside of the EU ${ }^{18}$ that contain, among others, provisions on the mutual recognition and enforcement of judgments rendered by the courts of the contracting parties. The majority of these treaties were concluded between the former Czechoslovakia (Czech and Slovak Federative Republic) before its dissolution at the end of 1992 and other socialist or people's democratic states. They continue to apply because the Czech Republic, as one of the two successor states, assumed all rights and obligations of Czechoslovakia, except for the rights and obligations linked to the territory of Slovakia. ${ }^{19}$

Bilateral treaties on legal assistance in civil matters are part of the Czech legal order and therefore one of the sources of Czech private international law. The mutual relationship between international treaties and national law in favour of international treaties is anchored in both the Czech Constitution (Art. 10) ${ }^{20}$ and the Czech PILA (Section 2). They have priority over national law provided the regulation of the issue in question is different. ${ }^{21}$ In relation to the Brussels Ibis Regulation, the EU rules affect only the application of bilateral treaties that the Czech Republic concluded with EU Member States, not with third countries. ${ }^{22}$

Bilateral treaties operate on the basis of reciprocity, and the provisions on the recognition and enforcement contained in these treaties apply only to judgments rendered by the courts of contracting parties that are mutually recognised under the same conditions. The particular rules for the recognition and enforcement of judgments in commercial matters may differ in individual treaties but generally there is no special recognition procedure required, enforcement is not subject to prior declaration of enforceability in the requested state and judgments given by the courts of a contracting party are

17 E.g., Regulation (EU) No 650/2012 of the European Parliament and of the Council of 4 July 2012 on jurisdiction, applicable law, recognition and enforcement of decisions and acceptance and enforcement of authentic instruments in matters of succession and on the creation of a European Certificate of Succession, Council Regulation (EC) No 4/2009 of 18 December 2008 on jurisdiction, applicable law, recognition and enforcement of decisions and cooperation in matters relating to maintenance obligations the Maintenance Regulation, Convention on the International Protection of Adults.

18 Their list is available at the website of the Czech Ministry of Foreign Affairs or Ministry of Justice. The Czech Republic has concluded such treaty with, e.g., Ukraine, Vietnam, Cuba, Mongolia, Uzbekistan, Tunisia, the former Soviet Union or the former Yugoslavia.

19 Article 5 para. 3 of Constitutional Act No. 4/1993 Coll. of the Czech National Council, of December 15, 1992, on Measures Related to the Dissolution of the Czech and Slovak Federative Republic.

20 Act No. 1/1993 Coll., Constitution of the Czech Republic.

21 KUČERA, Z. - PAUKNEROVÁ, M. - RŮŽIČKA, K. et al. Mezinárodní právo soukromé. Eighth edition, Plzeň - Brno: Aleš Čeněk - Doplněk, 2015, pp. 59-60; BŘÍZA, P. In: BŘÍZA, P. - BŘICHÁČEK, T. FIŠEROVÁ, Z. - HORÁK, P. - PTÁC̆EK, L. - SVOBODA, J. Zákon o mezinárodním právu soukromém. Komentár. Praha: C. H. Beck, 2014, pp. 13-14.

22 Art. 73 para. 3 Brussels Ibis Regulation. 
recognised and enforced in the territory of the other contracting party when final and enforceable in the country of origin and when no ground for non-recognition exists. All relevant treaties contain an exhaustive list of grounds for non-recognition, while individual grounds vary. As outlined below in Part 3, the refusal grounds anchored in the Czech PILA are mostly to be found among the refusal grounds in bilateral treaties. According to all relevant bilateral treaties, the lex fori is the law governing the enforcement procedure, and a review as to the merits of the judgment (révision au fond) in the country where recognition and enforcement is sought is not permitted.

\subsection{RELEVANT MULTILATERAL TREATIES BINDING FOR THE CZECH REPUBLIC}

The Czech Republic is also bound by multilateral treaties that unify the rules for the recognition and enforcement of judgments given by the courts in contracting states in commercial matters within their material scope. As an EU Member State the Czech Republic is bound by the regional Lugano Convention ${ }^{23}$ concluded in 2007 among the EU, Switzerland, Norway and Iceland which extends the application of the rules (including the rules for recognition and enforcement) of the Brussels I Regulation to the territory of the above-mentioned members of the European Free Trade Association (EFTA). In the field of international transport, the Czech Republic is bound by COTIF $^{24}$ and CMR $^{25}$ that provide for judgments given by competent courts pursuant to the provisions of the respective convention and enforceable in the state of origin to become enforceable in other contracting states on completion of formalities required in the state where enforcement is sought. ${ }^{26}$

On a global scale there are two recent international instruments on the recognition and enforcement of judgments in civil and commercial matters drafted by the Hague Conference that lay the foundations for the future effective circulation of judgments in commercial matters worldwide. Their aim is to enhance and facilitate cross-border trade by creating an international legal regime that provides greater predictability and certainty in relation to the global recognition and enforcement of foreign judgments. The Czech Republic, as well as the EU as an REIO, ${ }^{27}$ are members of the Hague Conference. When the EU adheres to the Judgments Convention, which falls in the area of exclusive external competence of the $\mathrm{EU}$, it will be automatically binding for the Czech Republic as a Member State. 28

The Hague Convention on Choice of Court Agreements that entered into force first in 2015 currently has 32 contracting parties; in addition to the EU and its Member States,

23 Convention on jurisdiction and the recognition and enforcement of judgments in civil and commercial matters.

24 Convention concerning International Carriage by Rail from 1980 modified by the Vilnius Protocol from 1999.

25 Convention on the Contract for the International Carriage of Goods by Road signed in 1956 in Geneva.

26 Art. 12 COTIF and Art. 31 para. 3 CMR.

27 Regional Economic Integration Organisation.

28 Opinion of the Court of Justice of 7 February 2006 on the competence of the European Community to conclude the new Lugano Convention on jurisdiction and the recognition and enforcement of judgments in civil and commercial matters (case No. 1/03), [2006] ECR I-1145. 
the convention is binding for Mexico, Singapore, and Montenegro. Economic giants the USA and China signed the convention, but have not yet ratified it. ${ }^{29}$ The aim of the convention is to ensure the effectiveness of choice of court agreements between parties in cross-border business transactions by unifying rules for the recognition and enforcement of judgments in civil and commercial matters given by the courts of contracting states designated in an exclusive choice of courts agreement. Pursuant to Arts. 8 and 9, any judgment rendered by the chosen court (that has effect and is enforceable in the state of origin) must be recognised and enforced in other contracting states, except where a ground for refusal applies. ${ }^{30}$ The convention requires neither special recognition proceedings, nor a declaration of enforceability prior to enforcement and does not permit a review of the merits of the judgment in the requested contracting state (Art. 8 para. 2).

The second and most recent international instrument is the above-mentioned Hague Judgments Convention that was concluded in July 2019 after years of not always smooth and easy negotiations ${ }^{31}$ and that has not yet entered in force. ${ }^{32}$ For the EU, negotiating the Hague Judgments Convention represented a priority project of the gradual construction of an external EU policy on judicial cooperation in civil and commercial matters. ${ }^{33}$ It is to be expected that the Hague Judgments Convention will be binding for the Czech Republic in the near future. Hopefully it will attract many states so that its unified legal framework will soon provide effective circulation of foreign judgments given by courts in commercial matters worldwide. ${ }^{34}$ The number of contracting states is very crucial for its success as, unlike the New York Convention, the Hague Judgments Convention's operation is based on reciprocity (Art. 1 para. 2).

The Hague Judgments Convention anchors uniform core rules, by setting minimum standards for the recognition and enforcement of judgments in civil and commercial matters among future contracting states but not preventing the recognition and enforcement of judgments under national law (Art. 15). It is a complementary instrument to the Convention on Choice of Court Agreements as it introduces in principal an identical circulation regime (Art. 4 and Art. 7). The convention does not contain direct jurisdictional rules, but it stipulates alternative bases for the recognition and enforcement that are enumerated in Arts. 5 and 6 . They shall act as indirect jurisdictional filters - connections that a requested state will accept as legitimate when asked to recognise or enforce

${ }^{29} \mathrm{HCCH} \mid \# 37$ - Status table. HCCH | Splash. [online]. Copyright (c) HCCH 1951. Accessed [May 20, 2020] at: https://www.hcch.net/en/instruments/conventions/status-table/?cid=98.

30 Outline of the Convention. Accessed [August 30, 2019] at: https://assets.hcch.net/docs/89be0bce-36c7 -4701-af9a-1f27be046125.pdf.

31 Van LOON, H. Towards a Global Hague Convention on the Recognition and Enforcement of Judgments in Civil and Commercial Matters. Collection of Papers of the Faculty of Law, University of Niš, 2019, Year LVIII, No 82, pp. 15-36. Accessed [August 30, 2019] at: http://www.prafak.ni.ac.rs/files/zbornik/sadrzaj /ZFull/PF_Zbornik_2018_82.pdf.

$32 \mathrm{HCCH} \mid \overline{\# 4} 1$ - Status table. HCCH | Splash. [online]. Copyright (C) HCCH 1951. Accessed [May 9, 2020] at: https://www.hcch.net/en/instruments/conventions/status-table/?cid=137.

33 Van LOON, op. cit., p. 30.

34 Critical assessment with respect of its future recently, e.g., SCHACK, H. Das neue Haager Anerkennungsund Vollstreckungsübereinkommen. IPRax, 2020, No. 1, pp. 1-7. 
a foreign judgment, independently of whether or not they match the direct rules for exercising jurisdiction. ${ }^{35}$

\section{ENFORCEMENT OF FOREIGN JUDGMENTS UNDER CZECH NATIONAL LAW}

National rules set in the Czech PILA remain the only legal basis for the enforcement of judgments in commercial matters rendered by courts in non-EU countries, provided no international treaty applies. Under Czech procedural law the enforcement of a foreign judgment means taking a coercive measure by a competent authority against a judgment debtor if the judgment debtor is unwilling to perform voluntarily, in the same manner that a judgment rendered by Czech courts would be enforced. 36 "In the same manner" means using the same procedures and methods of enforcement, but not necessarily under the same conditions. In order to be enforced, a foreign judgment has to be recognised by the Czech authorities.

\subsection{RECOGNITION AS PREREQUISITE FOR ENFORCEMENT}

Under Section 14 of the Czech PILA, two requirements must be fulfilled for the recognition of a foreign judgment: firstly, it has to be final in the state of origin; and secondly, it has to be recognised by the Czech authorities. The first condition implies that the judgment has become final under the law of the state of origin, which shall be certified by the competent foreign authority. Regarding the second condition, Czech authorities grant recognition provided none of the grounds for refusal of recognition pursuant Section 15 of the Czech PILA exists. The procedure of recognition varies with respect to the subject-matter of the judgment. Generally, in commercial matters, where monetary or other property claims are the subject-matter of a judgment, Czech law does not require a special recognition procedure; the conditions for recognition are assessed by courts or competent authorities in the course of the enforcement procedure. Pursuant to Section 16 para. 3 of the Czech PILA, a Czech court can order the enforcement of a foreign judgment in property matters by a reasoned decision provided the foreign judgment complies with the recognition requirements set out in the Czech PILA.

\subsection{GROUNDS FOR REFUSAL OF RECOGNITION}

Under the Czech PILA, the recognition of a judgment rendered by the courts of a non-EU country may only be refused based on one of the grounds listed in its Section 15. The provision has an exhaustive list of six refusal grounds analysed below

35 Study on the Hague Conference on Private International Law "Judgments Convention", 2018, p. 13. 301 Moved Permanently. [online]. Copyright (C [cit. 30. 8. 2019]. Accessed [August 30, 2019] at: https:// europeanciviljustice.files.wordpress.com/2018/04/studyforeuparliament-haguejudgmentsproject-2018 .pdf.

36 KUČERA, Z. - PAUKNEROVÁ, M. - RŮŽIČKA, K. et al. Mezinárodni právo soukromé. Eighth edition, Plzeň - Brno: Aleš Čeněk - Doplněk, 2015, p. 375. 
that are to be assessed by a court, some of its own motion, some on application by the judgment debtor. The recognising authority is not allowed to review the findings of fact and legal conclusions of the court of origin; Czech private international law follows the general principle of prohibition of révision au fond.

\subsubsection{TEST OF JURISDICTION}

Pursuant to Section 15 para. 1 lit. a) of the Czech PILA, foreign judgments will not be recognised where jurisdictional rules applied in the territory of the Czech Republic confer exclusive jurisdiction on Czech courts, i.e., jurisdiction in certain matters is conferred solely on Czech courts. In commercial matters there are no applicable exclusive jurisdictional rules in the Czech PILA, as jurisdictional rules in EU regulations and binding international treaties have to be considered too. Therefore, for example, Czech courts have to take account of the rules on exclusive jurisdiction in Art. 24 of the Brussels Ibis Regulation. Pursuant to this provision they have exclusive jurisdiction, among others, for disputes on rights in rem in immovable property and tenancies of immovable property situated in its territory, in disputes on the validity of the constitution, nullity, or dissolution of companies or the validity of the decisions of company organs provided the seat of the company is in the Czech Republic, or for disputes on the registration or validity of patents, trademarks, designs, or other similar rights required to be deposited or registered in the Czech Republic.

Czech authorities will also refuse to recognize of foreign judgments issued in proceedings where the court of origin would not have had jurisdiction if rules on jurisdiction applicable in the Czech Republic (including rules on jurisdiction in relevant EU Regulations and binding international treaties) had been applied, unless the defendant submitted voluntarily to the jurisdiction of the foreign court. This provision shall prevent the recognition of foreign judgments based on exorbitant rules of jurisdiction where there is no close connection between the subject-matter and the issuing state, whereby this connection is to be assessed under the Czech law. The Czech recognising authority conducts the test of jurisdiction of the court of origin ex officio, of its own motion (Section 15 para. 2 of the Czech PILA).

The test of jurisdiction of the court of origin is one of the main differences between the respective national rules in the Czech PILA applicable to the recognition of judgments rendered by the courts of non-EU countries, and the EU rules in the autonomous Brussels - Lugano regime applicable to the recognition of judgments rendered by the courts in both EU Member States and in three of the four EFTA Member States: Switzerland, Norway, and Iceland. Mutual trust in the functioning of the judicial systems of the EU and the EFTA Member States is one of the leading principles in the Brussels Lugano regime. Therefore, subject to certain exceptions, ${ }^{37}$ it is not allowed to use the test of jurisdiction to refuse recognition of judgments rendered in this territory.

The test of jurisdiction can also be found among the grounds for refusal of recognition in some bilateral treaties on legal assistance concluded by the Czech Republic (e.g.,

37 Exclusive jurisdiction and special jurisdiction protecting weaker parties in matters relating to insurance, consumer contracts and individual contracts of employment (see Art. 45/1, lit. e) Brussels I bis Regulation and Art. 35/1 Lugano Convention). 
with the former Yugoslavia, ${ }^{38}$ Ukraine ${ }^{39}$ or Cuba).$^{40}$ A judgment shall not be recognised if the judicial authority of the contracting party on whose territory the judgment was issued lacked the jurisdiction to decide according to the treaty or according to national law.

\subsubsection{LIS PENDENS AND RES IUDICATA}

Proceedings on the same subject-matter pending before a Czech court, provided they were initiated prior to the proceedings before a foreign court, hinder the recognition of a judgment rendered abroad (Section 15 para. 1 lit. b) of the Czech PILA). "The same subject-matter" is given by both the identity of the parties and the identity of the subject-matter (legal relation). Under the national procedural law, the identity of the subject-matter means the identity of the claim, i.e., the identity of the legal ground and the factual circumstances of the claim (the identity of action and/or result). ${ }^{41}$ To the best knowledge of the authors, there has so far been no case-law where Czech courts interpret lis pendens and res iudicatae with respect to foreign judgments given by the courts of a non-EU country. It remains to be seen whether Czech courts would give preference to the broader "EU approach" in interpreting the "same cause of action" in extra-EU relations. ${ }^{42}$

Recognition of a foreign judgment will also be refused when a final judgment has been issued on the same subject-matter either by a Czech court or a by a foreign court provided that such foreign judgment was recognised in the Czech Republic. The issuance date of the judgment is irrelevant in this context. It is sufficient that at the time when the conditions for the recognition of the foreign judgment are assessed either the Czech "hindering" judgment is final, or the foreign "hindering" judgment has been recognised by Czech authorities. "The same subject-matter" shall be interpreted as having an identical meaning as in the context of the lis pendens ground for refusal of recognition.

The Czech recognising court considers the lis pendens and res iudicata refusal grounds only on application of the party against which the foreign judgment is to be recognised, unless the court is otherwise aware of their existence (Section 15 para. 2 of the Czech PILA).

Both lis pendens and res iudicata refusal grounds are common in bilateral treaties on legal assistance (as for example in the treaty with Uzbekistan) ${ }^{43}$ In some cases, howev-

38 Art. 51 letter b) Treaty between the Czechoslovak Socialist Republic and the Socialist Federative Republic of Yugoslavia on Legal Assistance in Civil, Family and Criminal Matters (No. 207/1964 Coll.).

39 Art. 54 letter b) Treaty between the Czech Republic and Ukraine on Legal Assistance in Civil Matters (No. 123/2002 Coll. of Int. Treaties).

40 Art. 47 para. 1 letter b) Treaty between the Czechoslovak Socialist Republic and Cuban Republic on Mutual Legal Assistance in Civil, Family and Criminal Matters (No. 80/1981 Coll.).

41 Judgments of the Supreme Court of the Czech Republic, Case No. 25 Cdo 1751/98 dated 24. 3. 1999 and No. 25 Cdo 2503/2011 dated 25. 11. 2012.

42 Judgments of the Court of Justice of the European Union 144/86 (Gubish Maschienenfabrik v. Palumbo), C-406/92 (Tatry v. Maciej Rataj), C-39/02 (Maersk Olie \& Gas).

43 Art. 51 para. 1 Treaty between the Czech Republic and the Republic of Uzbekistan on Legal Assistance and Legal Relations in Civil and Criminal Matters (No. 133/2003 Coll. of Int. Treaties). 
er, the proceedings on the same subject-matter pending before a Czech court would not constitute a refusal ground (e.g., the treaty with the former Yugoslavia).

\subsubsection{BREACH OF FAIR TRIAL}

This ground for the refusal of recognition of foreign judgments in Section 15 para. 1 lit. d) of the Czech PILA aims to protect the fundamental procedural rights of the defendant by allowing Czech courts to carry out a limited test of procedure of the court of origin. The "defendant" is the judgment debtor in the recognising jurisdiction and the review can only be performed on his/her application, the nationality is irrelevant. The scope of review is limited, Czech courts may only investigate whether the defendant was precluded from participating duly in the proceedings in the state of origin. In particular, the court shall investigate whether pursuant to the procedural rules in the state of origin the summons to appear or the document instituting the proceedings were served on the defendant in due form, i.e., whether the defendant has been duly informed about the initiation of the proceedings and in sufficient time to be able to arrange for defence. Breach of fair trial as a ground for refusal of recognition can also be found in some bilateral treaties (e.g., with the former Yugoslavia). ${ }^{44}$

\subsubsection{INFRINGEMENT OF PUBLIC POLICY}

Infringement of public policy is one of the traditional grounds for the refusal of recognition of foreign judgments. It is anchored in both Czech national and European private international law. ${ }^{45}$ Pursuant to Section 15 para. 1 lit. e) of the Czech PILA foreign judgment shall be denied recognition when contrary to Czech public policy. Public policy is not defined in the statute, but according to the doctrine Czech public policy includes the principles of the social and state system of the Czech Republic and its law that have to be strictly respected. Therefore, not every inconsistency with the Czech legal order hinders recognition. It follows from the case-law of the Constitutional Court of the Czech Republic and the Court of Justice of the European Union that the public policy exception applies when the effects of a foreign judgment breach fundamental rights and freedoms, including the right to a fair trial. ${ }^{46}$ The scope of the fair trial protection goes further here than in Section 15 para. 1 lit. b) of the Czech PILA mentioned above. The judgment may be contrary to Czech public policy even in cases when the defendant was heard and was not precluded from raising objections against the claim in the proceedings in the country of origin, but the court of origin refused to consider the defendant's objections on the basis of purely formalistic grounds. ${ }^{47}$ Unlike the breach of fair trial pursuant Section 15 para. 1 lit. b) of the Czech PILA which is

44 Art. 51 letter c) Treaty between the Czechoslovak Socialist Republic and the Socialist Federative Republic of Yugoslavia on Legal Assistance in Civil, Family and Criminal Matters (No. 207/1964 Coll.).

45 With some exceptions, the EU regulations on private international law, including the Brussels I bis Regulation [Art. 45/1 lit. a)], allow for non-recognition of a foreign judgment whose effects would be manifestly contrary to the public policy of the requested state.

46 See e.g., judgments of the Constitutional Court of the Czech Republic II. ÚS 2455/09, I. ÚS 709/05 and judgments of the Court of Justice of the European Union C-7/98, Krombach v. Bamberski; C-38/98, Renault; C-341/04, Eurofood IFSC Ltd.

47 Judgment of the Constitutional Court of the Czech Republic No. I. ÚS 709/05. 
examined only on request, the Czech recognising authority performs the public policy test of its own motion.

Foreign judgments rendered in commercial matters are usually in line with Czech public policy when the test is applied relating to substantive law rules. More frequently this ground for refusal becomes relevant with respect to procedural irregularities in the proceedings in the state of origin. One of the rare cases when Czech courts may apply the public policy refusal ground relating to substantive law involves the enforcement of punitive damages judgments, as this concept does not correspond with the compensatory function of damages in Czech legal doctrine. However, not every foreign judgment ordering the defendant to pay punitive damages is considered contrary to Czech public policy. The Czech Supreme Court held that the recognition of a punitive damages judgment cannot be denied without further analysis, even though the Czech private law does not contain this concept. The mere fact that punitive damages are unknown in Czech law cannot trigger the public policy refusal ground. The assessment has to be done in relation to whether the financial amount awarded is disproportionate with regard to the damage sustained. According to the Czech Supreme Court, recognition can only be refused if the amount of punitive damages is manifestly disproportionate with regard to the damage sustained, representing disproportionate interference with the right to property stipulated in Art. 11 para. 1 of the Charter of Fundamental Rights and Freedoms of the Czech Republic, which constitutes part of the Czech constitutional system. ${ }^{48}$

Public policy reservation as the most traditional ground for refusal of recognition is also anchored in most of the relevant bilateral treaties, but not in all of them. If Czech courts are deciding on the recognition of, e.g., an Uzbek ${ }^{49}$ or a Russian $^{50}$ court decision in commercial matters, they will not assess whether it complies with the lex fori public policy. It brings up the question whether a Czech court would find a legal basis to refuse recognition of an Uzbek or Russian court decision that is manifestly contrary to Czech public policy.

\subsubsection{LACK OF RECIPROCITY}

The requirement of reciprocity in Section 15 para. 1 lit. f) of the Czech PILA represents another traditional ground for refusal of recognition that is often found in national legislation. Pursuant to this provision the existence of reciprocity, which the recognising authority has to asses of its own motion, is required only in cases when the foreign judgment is aimed against a Czech national or a Czech legal entity. Should the foreign judgment be aimed against a foreigner or a foreign legal entity, the recognising authority does not have to ascertain whether reciprocity is guaranteed between the Czech Republic and the state of origin; lack of reciprocity does not prevent recognition. If relevant, reciprocity does not have to be guaranteed formally, i.e., neither by an international treaty, nor by a declaration of reciprocity. According to the case-law of

48 Decision of the Supreme Court of the Czech Republic from August 22, 2014, Case No. 30 Cdo 3157/2013.

49 See Art. 51 Treaty between the Czech Republic and the Republic of Uzbekistan on Legal Assistance and Legal Relationships in Civil and Criminal Matters (No. 133/2003 Coll. of Int. Treaties);

50 Art. 60 Treaty between the Czechoslovak Socialist Republic and the Union of Soviet Socialist Republics on Legal Assistance and Criminal Matters (No. 95/1983 Coll.); the treaty is applied in relation to some of the successor states, the most significant being the Russian Federation. 
the Czech Supreme Court material reciprocity is sufficient. Reciprocity is considered as guaranteed if the courts of the state of origin recognise Czech judgments on similar subject-matters under similar conditions. Material reciprocity shall be evidenced by the relevant legal act of the state of origin or by the standing practice of the state authorities.

The question arises as to how to assess reciprocity in cases where the standing practice of foreign state authorities is unknown in the Czech Republic and the law of the state of origin provides only general grounds for the refusal of recognition of foreign judgments. The Czech Supreme Court held that it is sufficient to consider reciprocity as guaranteed if the law of the state of origin allows the recognition of foreign judgments. ${ }^{51}$ The Supreme Court thus sided with the opinion of some experts, ${ }^{52}$ which, however, is not accepted unanimously in the doctrine. ${ }^{53}$ The assessment of whether or not reciprocity is guaranteed is based on the rules on recognition laid down in the law of the state of origin. The Czech Ministry of Justice assists judges when reciprocity has to be ascertained (Section 13 of the Czech PILA), but they are not bound by ministerial communications. Where bilateral treaties on legal assistance apply, the assessment of reciprocity is not necessary, as it is clearly stipulated in their text. ${ }^{54}$

\subsection{PROCEDURES FOR ENFORCEMENT OF FOREIGN JUDGMENTS IN COMMERCIAL MATTERS}

Should a judgment debtor fail to fulfil an obligation imposed by a foreign judgment in property matters, the judgment creditor may apply for judicial enforcement before a court. ${ }^{55}$ Enforcement is always governed by Czech national procedural law, no matter what rules on recognition and enforcement apply. Czech law offers two procedures of enforcement, the judgment creditor can choose and the court is bound by his choice.

In the Czech Republic, judgment creditors may choose between judicial enforcement under the Civil Code of Procedure and enforcement by bailiffs under the Enforcement Code. ${ }^{56}$ Judgment creditors usually consider the enforcement by bailiffs as more effective and therefore preferable. Pursuant to the Enforcement Code, judgment creditors are not obliged to specify a concrete method of enforcement and do not have to provide details of the judgment debtor's assets. It is the task of the bailiff to find the assets of the debtor. But the requirements foreign judgments have to meet to be eligible for enforcement by bailiffs are stricter than for judicial enforcement. Enforcement by bailiffs is only admitted where the foreign judgment was, on application of the judgment

51 Decision of the Supreme Court of the Czech Republic from December 18, 2014, Case No. Cdo 3753/2012.

52 BŘICHÁČEK, T. In: BŘÍZA, P. - BŘICHÁČEK, T. - FIŠEROVÁ, Z. - HORÁK, P. - PTÁČEK, L. SVOBODA, J. Zákon o mezinárodním právu soukromém. Komentár̆. Praha: C. H. Beck, 2014, p. 107.

53 PAUKNEROVÁ, M. Dvojí exequatur a mezinárodní právo soukromé. In: KYSELOVSKÁ, T. - SEHNÁLEK, D. - ROZEHNALOVÁ, N. (eds.). In varietate concordia: soubor védeckých statí $k$ poctě prof. Vladimíra Týče. Brno: Masarykova univerzita, 2019, Spisy Masarykovy univerzity, Edice Scientia: řada teoretická, 651, (online), p. 258.

54 E.g., Art. 50 para. 1 Treaty between the Czechoslovak Socialist Republic and the Socialist Federative Republic of Yugoslavia on legal assistance in civil, family and criminal matters (No. 207/1964 Coll.).

55 Sections 251-351a Act No. 99/1963 Coll., Civil Code of Procedure.

56 Act No. 120/2001 Coll., on Court Bailiffs and Enforcement Activities (Enforcement Code). 
creditor, first recognised in special proceedings on recognition or declared by a Czech court to be enforceable pursuant to a directly applicable EU instrument or international treaty. ${ }^{57}$ With respect to foreign judgments given by non-EU courts, pursuant to Section 16 para. 2 of the Czech PILA Czech courts decide in special proceedings on recognition on the application of the judgment creditor, and only then can the foreign judgment be enforced by bailiffs. With respect to foreign judgments given by the courts of non-EU countries, the two enforcement procedures are not equally accessible. If the judgment creditor is not able to specify how the judgment shall be enforced (for example in the case when the judgment creditor has no information on the assets of the judgment debtor in the territory of the Czech Republic) ${ }^{58}$ he or she cannot apply directly for enforcement by bailiff but has to apply first for judicial recognition of the judgment. Such recognition procedure may last long enough (several months, perhaps years) to provide the judgment debtor, who has been informed by the court, with the opportunity to discard his or her assets and minimise the judgment creditor's chance of satisfaction of his or her claims. ${ }^{59}$

\section{CONCLUSION}

In international trade it is essential to have effective enforcement procedures available to enforce judgments abroad. Enforcement is usually the final step judgment creditors take to recover their claims where judgment debtors are reluctant to voluntarily fulfil their obligations. And vice versa, the growing relevance and volume of international trade certainly influences the content of legal rules, including rules on recognition and enforcement of foreign judgments rendered in commercial matters. The closer and more intense the trade connections between states or within regional organisations (like the EU or EFTA) are, the simpler, swifter, and more predictable the legal regime of recognition and enforcement of foreign judgments is required and negotiated in supranational legal instruments.

Czech national rules of private international law allow recognition and enforcement of judgments in commercial matters rendered by courts of states which are neither members of the EU (nor EFTA), nor parties to a binding multilateral or bilateral treaty that contains rules on recognition and enforcement of judgments in commercial matters. But the predictability of such a recognition or enforcement is quite limited given the requirements set by the Czech PILA. The lack of reciprocity is likely to be the most frequently applied ground for non-recognition by Czech courts as it is rather difficult for

57 Section 37 para. 2 lit. b) Enforcement Code.

58 Section 261 para. 1 Civil Code of Procedure.

59 Under the recent case-law of the Czech Supreme Court, the same applies for foreign arbitral awards, despite the fact that they are enforceable under the New York Convention (see judgments Case No. 20 Cdo 1165/2016, Case No. 20 Cdo 5882/2016, Case No. 20 Cdo 1754/2018). In order to facilitate the access to the enforcement of foreign judgments and arbitral awards by bailiffs, the Czech Government has submitted to the Parliament a draft of amendments to the relevant procedural provisions. The proposed amendments allow the filing of a joint application for recognition and for enforcement by a bailiff (draft of amended Section 35 para. 12 Enforcement Code). See the official website of the Chamber of Deputies of the Parliament of the Czech Republic: http://public.psp.cz/en/sqw/historie.sqw?o=8\&T=545. 
both the courts and the judgment creditors to find out whether Czech judgments were granted recognition in the state of origin under its law or based on the standing practice of its courts.

Removing obstacles to mutual recognition and enforcement of judgments in commercial matters worldwide is certainly a significant challenge in the economically globalized world. The Hague Conference made a big step forward when negotiating the 2005 Choice of Court Agreements Convention and the 2019 Hague Judgments Convention. Now, the ball is in the court of states. By joining these conventions, a global legal basis for mutual recognition and enforcement of judgments would be established, and reciprocity would no longer be a global obstacle to recognition and enforcement. It would become a global principle.

doc. JUDr. Mgr. Magdalena Pfeiffer, Ph.D.

Faculty of Law, Charles University, Prague

pfeiffer@prf.cuni.cz

JUDr. Marta Zavadilová, Ph.D.

Faculty of Law, Charles University, Prague

zavadilovam@prf.cuni.cz 